\title{
A NEW GENUS AND A NEW SPECIES OF DIATOM FROM BRAZILIAN MARINE WATERS
}

Clóvis Teixeira*

In this paper I refer to a new genus and a new species of diatom of the family Solenoideae from Brazilian coastal waters.

The material was collected at Ubatuba (São Paulo State), Bay of Sepetiba (Rio de Janeiro, DF) and Abrolhos Banks (Bahia State), Brazil.

The generic name has been given in honour to Mr. F. C. Müller-Melchers to whom I am indebted for my initiation to diatom investigations. I am also grateful to Dr. Fr. Hustedt (Bremen, Germany), a renown diatom specialist, who kindly confirmed the new genus and species; to Profa. Maria Helena de Araujo Andrade for taking the photographs that illustrate this paper. To all my very best thanks.

\section{Genus Melchersiela n.g.}

The new genus here described is characterized by its elongated frustules which are circular, slightly conical and convex in valvar view.

The girdle view is composed of numerous intercalary bands, a typical character of the Solenoideae.

This genus is included in the subfamily of Lauderiinae owing to its fundamental characteristics. It presents certain affinities with Guinardia of the subfamily Rhizosoleniinae.

However, this diatom differs from the other genus of the subfamily Lauderiinae specifically in the typical manner of connection Brazil.

- Supported by a grant in aid of the National Research Council, Rio de Janeiro, 
of the cells, in the formation of colonies as well as in the complete absence of marginal spines and apiculi. This connection with a small cushion form is found on the margin of the valva; in case of two specimens they are disposed opposite to each other.

\section{Melchersiela hexagolis n.sp.}

(Pls. I-II)

Besides the characteristics of the genus this new species presents the following specific characteristics: the primary membrane is formed by a reticulation of poligonal areola (Pl. I, Fig. 4a) ; the number of areola diminishes gradually from the center to the periphery of the valva (Pl. I, Fig. 4).

The diameter of the valvar region varies from $0.040 \mathrm{~mm}$ to $0.075 \mathrm{~mm}$. A small depression is found on the valvar face where the cushion is sustained (Pl. II, Fig. 1). The girdle region is generally twice or three times larger than the valvar diameter which is 120 to $250 \mu$ long (Pl. II, Figs. 1-3).

Each cells shows numerous intercalary bands in rings with poligonal structure forming a network of areola. The areola are slightly hexagonal presenting 19 areola in $0.01 \mathrm{~mm}$ transversally and 16 in $0.01 \mathrm{~mm}$ longitudinally.

Numerous discoid cromatophores are scattered in the cellular protoplasm.

\section{R E S U M O}

Descrevem-se no presente trabalho um novo gênero e uma nova espécie de diatomácea marinha, pertencente à família Solenoideae, subfamília Lauderiinae.

O material foi colhido em Ubatuba (São Paulo), na Baia de Sepetiba (Rio de Janeiro, DF) e em Abrolhos (Bahia).

Embora o novo gênero apresente certas afinidades com o gênero Guinardia, fica melhor classificado entre os gêneros da subfamília Lauderiinae, dos quais difere pela maneira muito típica de conexão das células na formação das colônias, bem como pela completa ausência de espinhos ou dentículos marginais.

O nome genérico foi dado em homenagem ao Prof. F. C. Müller-Melchers, a quem devo minha iniciação no estudo das diatomáceas. 
Fig. 1 - Vegetative cell just before division.

Fig. 2 - Girdle view showing the numerous intercalary bands.

Fig. 3 - Vegetative cell just after division.

Fig. 4 - Half of a cell showing areolation.

Fig. 4a - More highly magnified.

Fig. 5 - Vegetative cell showing chromatophores. 
Teixeira, C. - A new genus... diatom...
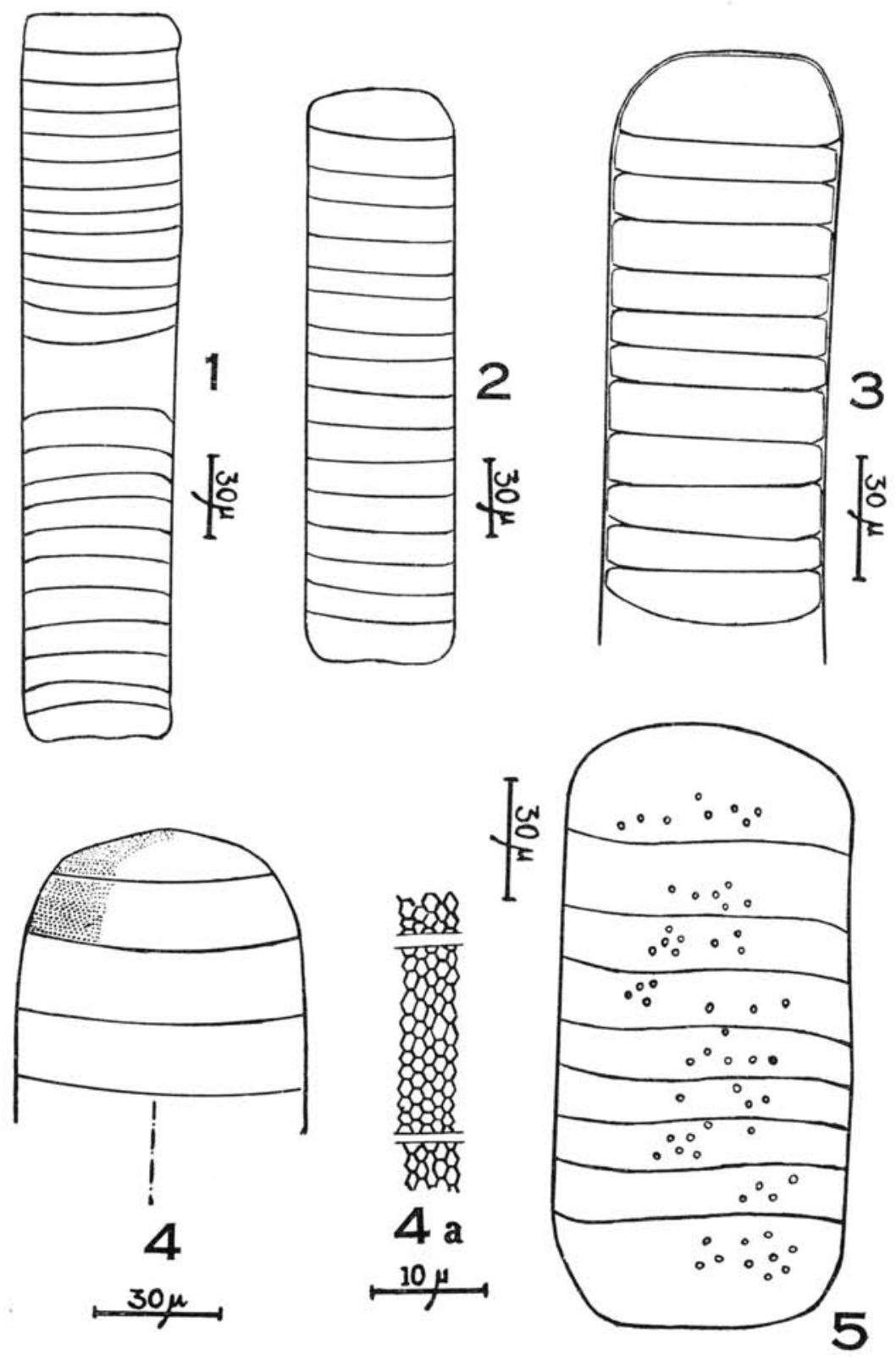
$-35-$

\section{PLATE II}

Fig. 1 - Cell showing areolation and the depression on the valve.

Fig. 2-3 - A part of colony showing the characteristic manner of connection between the cells. 
Teixeira, C. - A new genus... diatom...

PLATE II
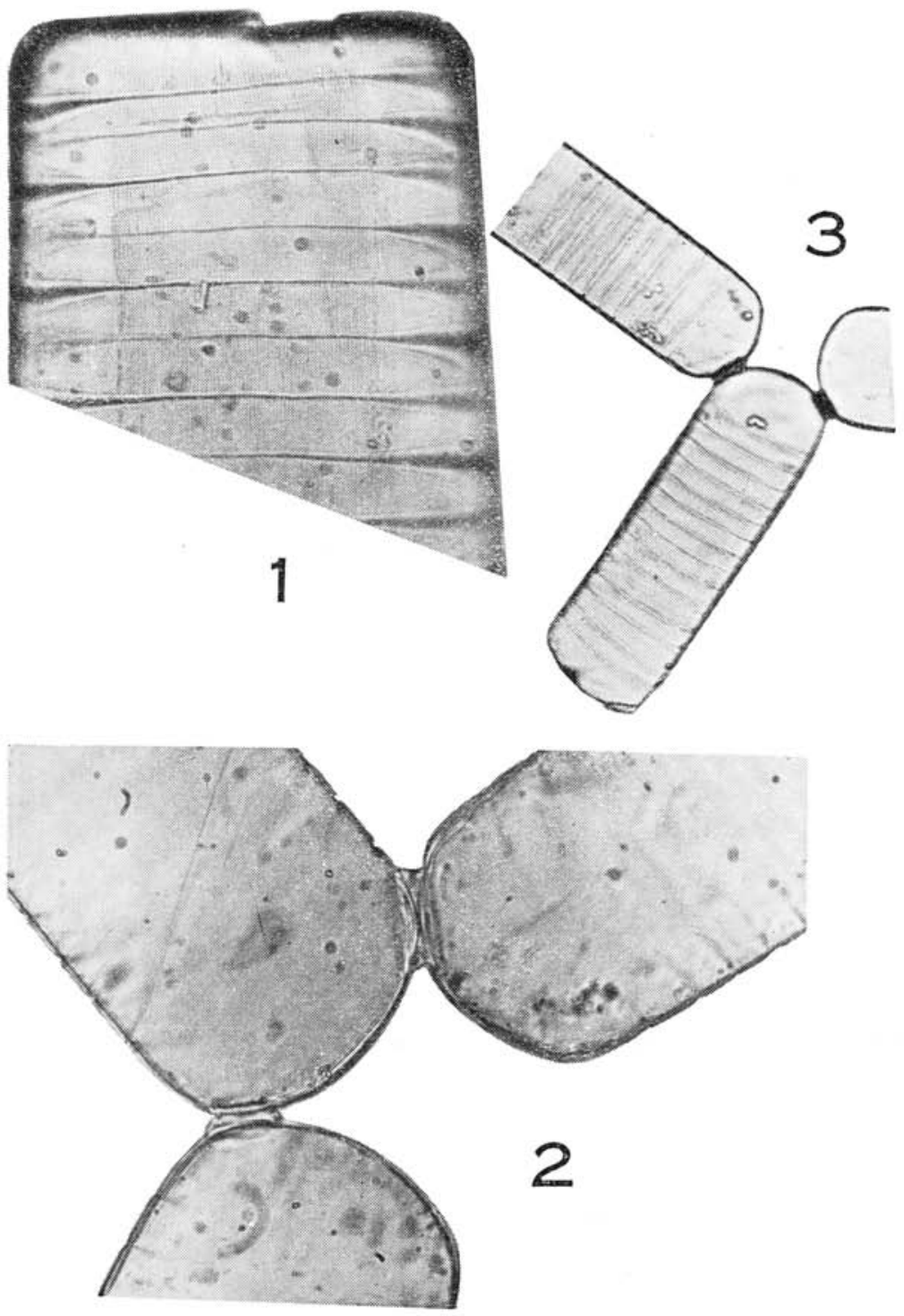